\title{
Grain size constraints on arsenic concentration in shallow wells of Nawalparasi, Nepal
}

\author{
*Suresh Das Shrestha ${ }^{\prime}$, Tom Brikowski ${ }^{2}$, Linda Smith ${ }^{2}$, and Tai-Chyi Shei ${ }^{2}$ \\ 'Central Department of Geology, Tribhuvan University, \\ Kathmandu, Nepal \\ ${ }^{2}$ Geoscience Program, University of Texas at Dallas, USA \\ (*Email:suresh1958@hotmail.com)
}

\begin{abstract}
Occurrence of arsenic in shallow aquifers was studied from the Nawalparasi district in west Nepal. A higher concentration of arsenic was found in the wells from the north as compared to those from the south. The arsenic level in the north reaches a maximum of $694 \mathrm{ppb}$ as compared to a value of $27 \mathrm{ppb}$ in the south near the Nepal-India border. The arsenic concentration analyses carried out in selected sites from March to September 2003 indicate a large variation (exceeding 200\%) in the north as compared to the central and southern regions. A general increase in grain size from north to south was observed in the well logs. Generally, fine sediments like clay and silt constitute more than $80 \%$ of the drilled depth in the north (i.e., at Panchnagar), while the fines are about $32 \%$ in the south (i.e., at Bhujawa). This type of grain size distribution is in contrast to the generally observed fining-southwards pattern in the Terai.
\end{abstract}

\section{INTRODUCTION}

Shallow aquifers of the Nawalparasi district in the Terai region of west Nepal are now known for their widespread arsenic contamination. Various agencies, such as Nepal Red Cross Society (NRCS), Department of Water Supply and Sewerage (DWSS), Rural Water Supply and Sanitation Support Program (RWSSSP), and FINNIDA, are involved in testing wells in the district to study the extent of contamination. As a result, various 'hot spots' with a high arsenic content have been identified. Panchnagar, Pratapur, the Ramgram Municipality and Manari are some of the 'hot spots' in the area (Fig. 1). However, a considerable variation exists even within adjacent wells. Little is known yet as to how and why certain wells have a high arsenic content while similar wells nearby are relatively arsenic-free. It has been observed that most of the tubewells with a high arsenic concentration are shallower than $50 \mathrm{~m}$, and those deeper than $50 \mathrm{~m}$ have a comparatively less arsenic concentration (Shrestha et al. 2004).

To reveal the seasonal variation in arsenic concentration, wells were monitored from various Village Development Committees (VDCs) of Nawalparasi (Fig. 1). Further more, geology of the area, NRCS well logs, and hydrogeological parameters were also studied. The monitored wells exhibited high ( $>50 \mathrm{ppb})$, moderate $(10-50 \mathrm{ppb})$, and low $(<10 \mathrm{ppb})$ arsenic contents.

\section{PRESENT ARSENIC SCENARIO}

There are not many wells in the hills or dun valleys in the eastern part of the district, as compared to the Terai belt in the south and southwest. All those wells sampled by NRCS in the hilly belt contain little arsenic in water (NRCS 2001). The Argayuli, Benianipur, Daune, Kalhuwa, and Pithauli villages show a concentration of arsenic below $10 \mathrm{ppb}$.

The data exhibit a great variation in arsenic content in the wells even within a single VDC or ward (Table 1). The arsenic distribution map of the study area (Fig. 1) shows that the central and northern portions of the Terai belt of Nawalparasi have a higher arsenic concentration than the southern region. A majority of wells from the northern and central parts exhibit a high arsenic concentration (i.e., above $50 \mathrm{ppb}$ ), and hence the "hot spots" are confined there. On the other hand, most of the VDCs in the south, near the Nepal-India border, have a concentration of less than 10 ppb. Only one VDC in the south showed a relatively high arsenic concentration.

\section{ARSENIC VARIATION}

Water samples were collected from 19 tubewells and 3 dug wells from 7 VDCs of Nawalparasi in March, May, July, and September 2003. At the same time, their piezometric levels were also measured. The samples were analysed using AAS 
Table 1: Arsenic concentration variation in the study area

\begin{tabular}{|c|c|c|c|c|c|c|c|c|}
\hline \multirow[t]{2}{*}{$\mathbf{S} / \mathbf{N}$} & \multirow[t]{2}{*}{ Well No. } & \multirow[t]{2}{*}{ VDC } & \multirow{2}{*}{$\begin{array}{l}\text { Initial concentration (ppb) } \\
(\text { Shres tha et al. 2004) }\end{array}$} & \multicolumn{4}{|c|}{\begin{tabular}{|c} 
Concentration (ppb) in monitored wells, \\
2003 \\
\end{tabular}} & \multirow{2}{*}{$\begin{array}{c}\text { Max. } \\
\text { variation }\end{array}$} \\
\hline & & & & March & May & July & September & \\
\hline 1 & RN17 & Ramnagar & 70 & 123 & 80 & 74 & 79 & 49 \\
\hline 2 & RN3 & Ramnagar & 71 & 102 & 60 & 57 & 69 & 45 \\
\hline 3 & 8761 & P.Nagar & 226 & 404 & 130 & 265 & 180 & 274 \\
\hline 4 & 8764 & P.Nagar & 232 & 373 & & & & \\
\hline 5 & 8765 & P.Nagar & 436 & 694 & 310 & 510 & 405 & 384 \\
\hline 6 & 996 & P.Nagar & 99 & 254 & 150 & 165 & 130 & 124 \\
\hline 7 & 8759 & P.Nagar & 95 & 357 & 160 & 175 & 115 & 242 \\
\hline 8 & 8754 & P.nagar & 0 & & 5 & 6 & 5 & 1 \\
\hline 9 & 8778 & Tilakpur & 277 & 483 & 280 & 325 & 215 & 268 \\
\hline 10 & 8879 & Tilakpur & 199 & 335 & 170 & 215 & 135 & 200 \\
\hline 11 & 8773 & Tilakpur & 0 & & 5 & 5 & 5 & \\
\hline 12 & DW2 & Tilakpur & & & & $<5$ & $<5$ & \\
\hline 13 & 743 & Jahada & 5 & & 20 & 23 & 12 & 11 \\
\hline 14 & 744 & Jahada & 98 & 166 & 120 & 115 & 96 & 70 \\
\hline 15 & 564 & Sarawal & 101 & 102 & & & & \\
\hline 16 & 572 & Sarawal & 6 & & 20 & 21 & 10 & 11 \\
\hline 17 & 774 & Somani & 4 & & 5 & 6 & 5 & 1 \\
\hline 18 & 777 & Somani & 112 & 122 & 140 & 155 & 100 & 55 \\
\hline 19 & 768 & Somani & 58 & 58 & 80 & 78 & 47 & 33 \\
\hline 20 & DW 1 & Somani & & & 30 & 28 & 23 & \\
\hline 21 & DW3 & Pratapur & & & & 45 & 23 & \\
\hline
\end{tabular}

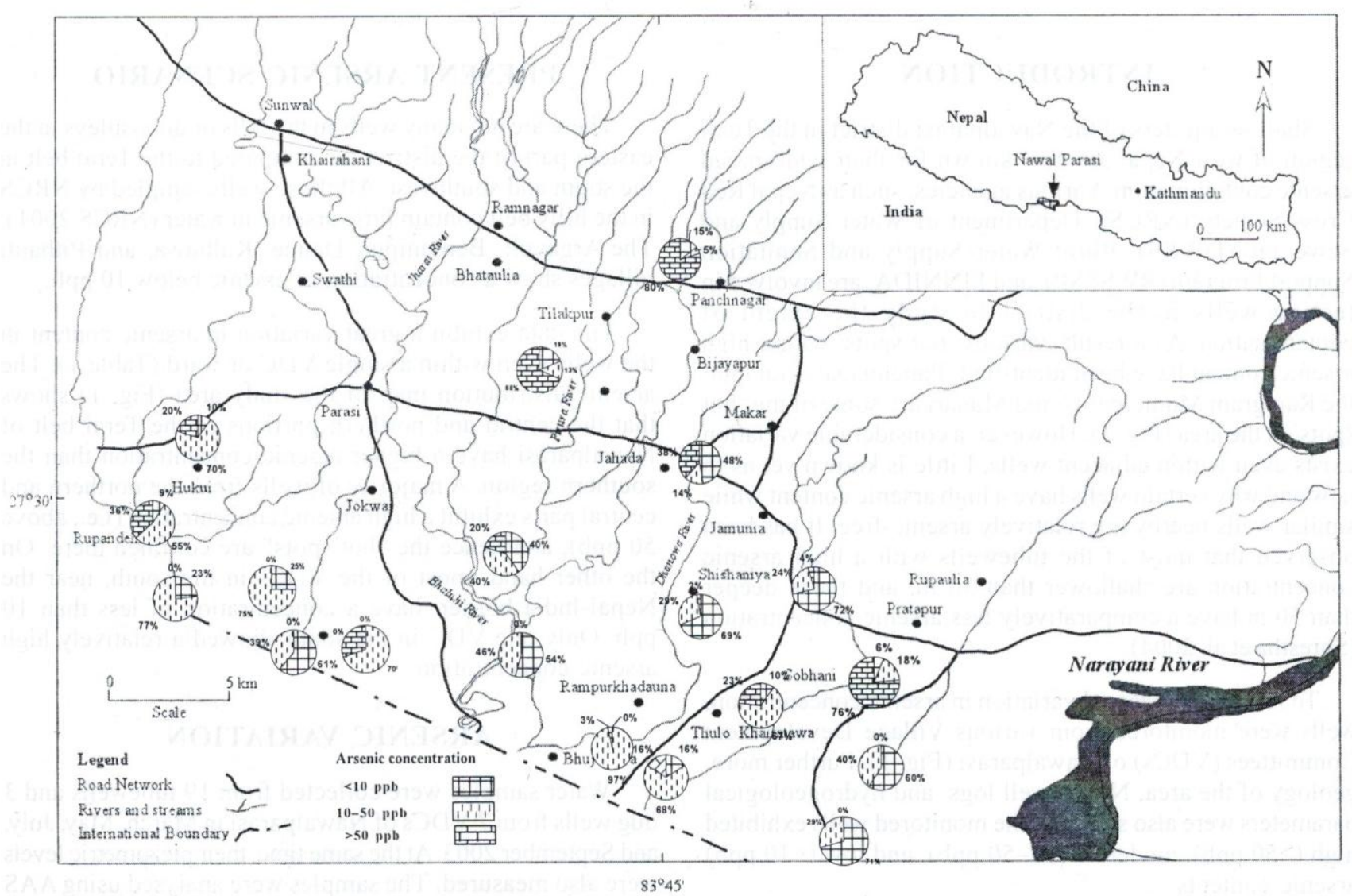

Fig. 1: Map of the study area showing the variation in arsenic content 
(Atomic Absorption Spectrometer). Out of 19 tubewells, 5 had a concentration of arsenic below $50 \mathrm{ppb}$ (Table 1). Initially, only the wells with a high arsenic concentration were taken into consideration, but their number was increased subsequently by including 6 other neighbouring wells. Consequently, the initial observations are not available for the latter wells.

The analysis (Table 1) depicts that the arsenic concentration in wells is the highest in March and lowest in September. On the other hand, the arsenic content is also quite low in May, one of the driest months of the year. The maximum arsenic variation in a well is up to $210 \%$, whereas the minimum is $20 \%$. The maximum fluctuation is observed in the wells with a relatively high arsenic content (Table 1).

\section{LITHOLOGY}

The lithologs from Nawalparasi (Fig. 2) depict very thick, yellow and black clay beds in the north and they decrease considerably in thickness to the south. The wells in the southernmost part (i.e., at the vicinity of Bhujawa) contain about $32 \%$ of fines (i.e., silt and clay) on average. Similarly, the wells at Thulo Khiratawa, lying further north of Bhujawa, have about $52 \%$ of average fines. In the central region, the content of fines ranges from $45 \%$ to $62 \%$ at Sobhani and Jahada, respectively. Similarly, in the northern parts of the Ramnagar and Panchnagar VDCs, the fines constitute $80 \%$ and $90 \%$, respectively. Despite a large lateral variation, above data clearly point out to a general coarsening-southwards trend of sediments. This type of distribution may have been influenced by the proximity to the Bhabar zone. For example, the sediments at Sunwal, which is close to the Siwalik foothills in comparison to Panchnagar (Fig. 3), are represented by coarse-grained sediments. However, such an interpretation is inconsistent with the observations made at Ramnagar and Panchnagar (just south of the Bhabar zone), where a thick sequence of clay and silty clay is observed in contrast to the general fining-southwards trend (Fig. 2, 3). Generally, the sediments in the south are comparatively coarse-grained. The well logs show coarse sand and gravel at a depth of $9 \mathrm{~m}$.

Despite similarities in lithology, arsenic concentration may vary significantly within a short distance. The village of Sobhani is a good example (Fig. 2), where the concentration ranges from $34 \mathrm{ppb}$ to $178 \mathrm{ppb}$. Similarly, more than $80 \%$ of the wells at Panchnagar have a concentration above $50 \mathrm{ppb}$, but well number 8764 is free of arsenic. However, their lithology is not very much different from that of well number 8761 with a concentration of $226 \mathrm{ppb}$.

\section{PIEZOMETRIC LEVEL FLUCTUATION}

The recorded piezometric levels do not give a clear picture regarding the seasonal variation in arsenic concentration (Fig. 4). Many wells exhibit the highest piezometric level in March, which is inconsistent with the fact that March is one of the driest months of the year. On the other hand, the lowest piezometric level was recorded in July. Out of 19 wells, only one well showed the highest piezometric level in September. In fact, a number of wells recorded quite low piezometric levels in September.

\section{DISCUSSION}

The water samples were collected in March (premonsoon period with a little rain), May (the driest month when the water table is expected to be the lowest), July (monsoon period), and September (post-monsoon period presumably with a high water table). A high arsenic concentration was expected in the dry period (i.e., March and May). Similarly, during the monsoon and post-monsoon months of July and September, the arsenic concentration was expected to be significantly low due to dilution.

However, in contrast to the assumptions, many wells recorded the highest piezometric level in March. The arsenic concentration was also the highest in this month (Fig. 4). As expected, many wells showed the lowest piezometric level in May, and the arsenic concentration, though not the lowest, was also quite low. The piezometric levels showed an irregular pattern even in September. Some wells recorded the highest level while others showed the lowest. The arsenic values in the monsoon months of July and September fall in between those of March and May.

Though no strong correlation exists between the fluctuation of piezometric level and arsenic concentration, the general pattern of low arsenic concentration-low piezometric level, high arsenic concentration-high piezometric level can be visualised. This may indicate that arsenic is brought into the well with the inflow of water rather than being dissolved from the sediments in the vicinity of the wells. Researchers in Bangladesh and West Bengal (India) have stressed that the annual fluctuation of water table (about $5 \mathrm{~m}$ ), affects the arsenic movement in shallow layers, while at greater depths, groundwater moves slowly in response to the low regional gradient, and hence the vertical and lateral spread of the contaminants is slow (MLGRDC and DFID 1998).

Though in the southern part of the study area, many wells having the lowest arsenic concentration show a significant increase during the study period, they are still below the WHO limit of $10 \mathrm{ppb}$ to safe drinking water. Well numbers 8754,774 , and 949 have a concentration of less than $0.005 \mathrm{mg} / \mathrm{l}$, but in some months the concentration increases abruptly and exceeds significantly the WHO limit. The fluctuation is not so abrupt in the northern part, but the concentration is very high. Well number 8765 at Panchnagar showed the highest concentration of arsenic (694 ppb) in March, while it reduced to $310 \mathrm{ppb}$ in May. But, again it increased to $510 \mathrm{ppb}$ in July only to decrease to $405 \mathrm{ppb}$ in September. Another well number 8778 in Tilakpur showed the value of $483 \mathrm{ppb}$ in March, which decreased to $280 \mathrm{ppb}$ in May. Its concentration rose again to $325 \mathrm{ppb}$ in July, and 

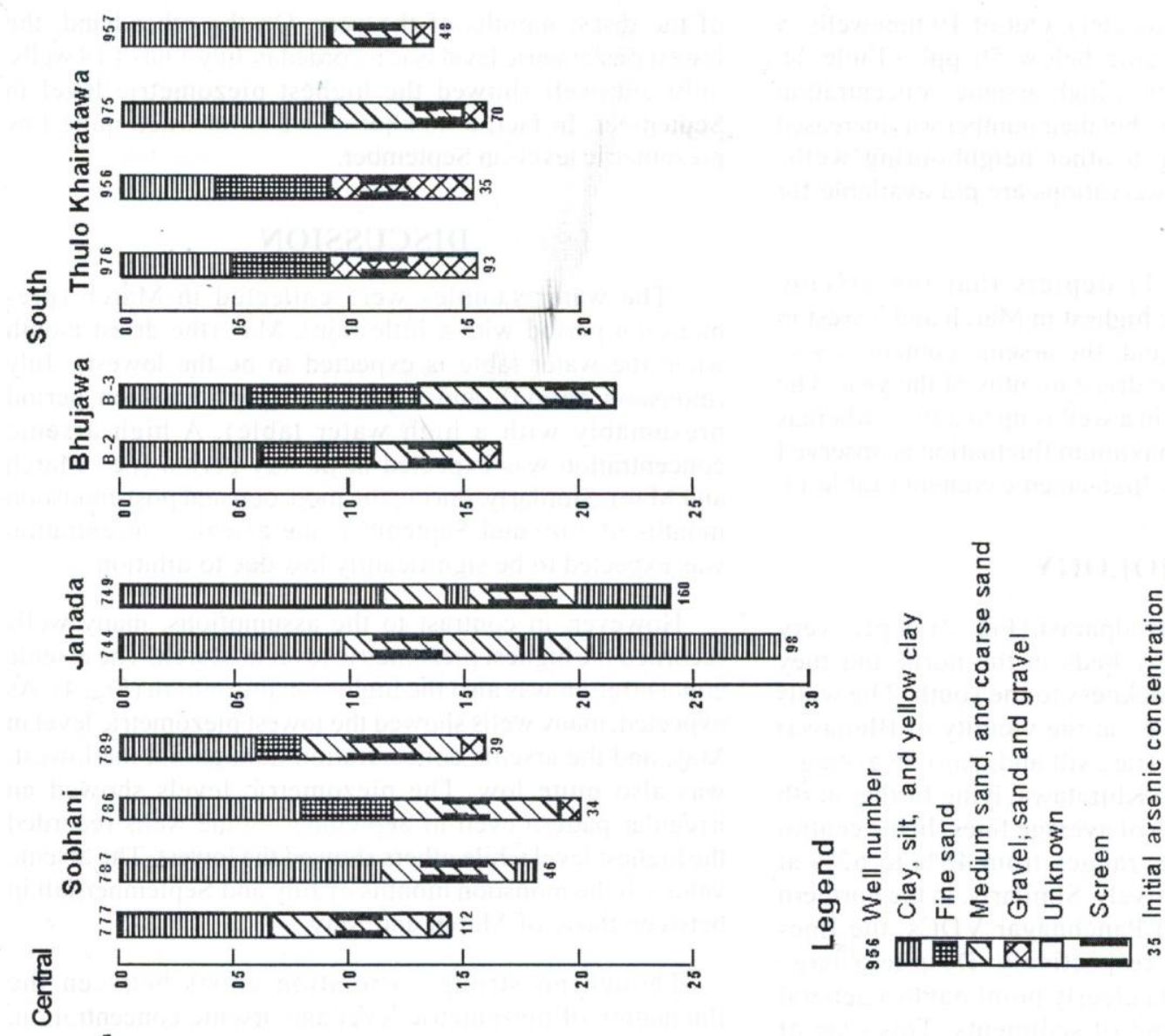

总

gั

气

๕

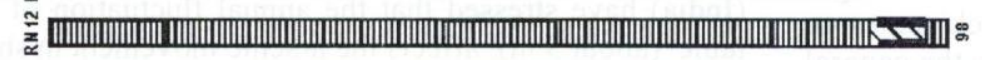

s

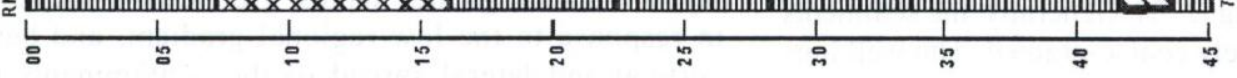

: :

פ

g:

:

हूँ है :

ฐ :

气 : :

5. :

:

ક

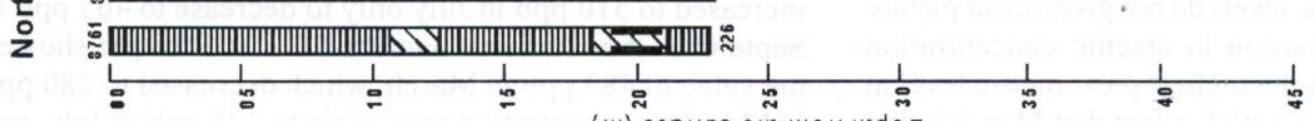

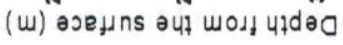




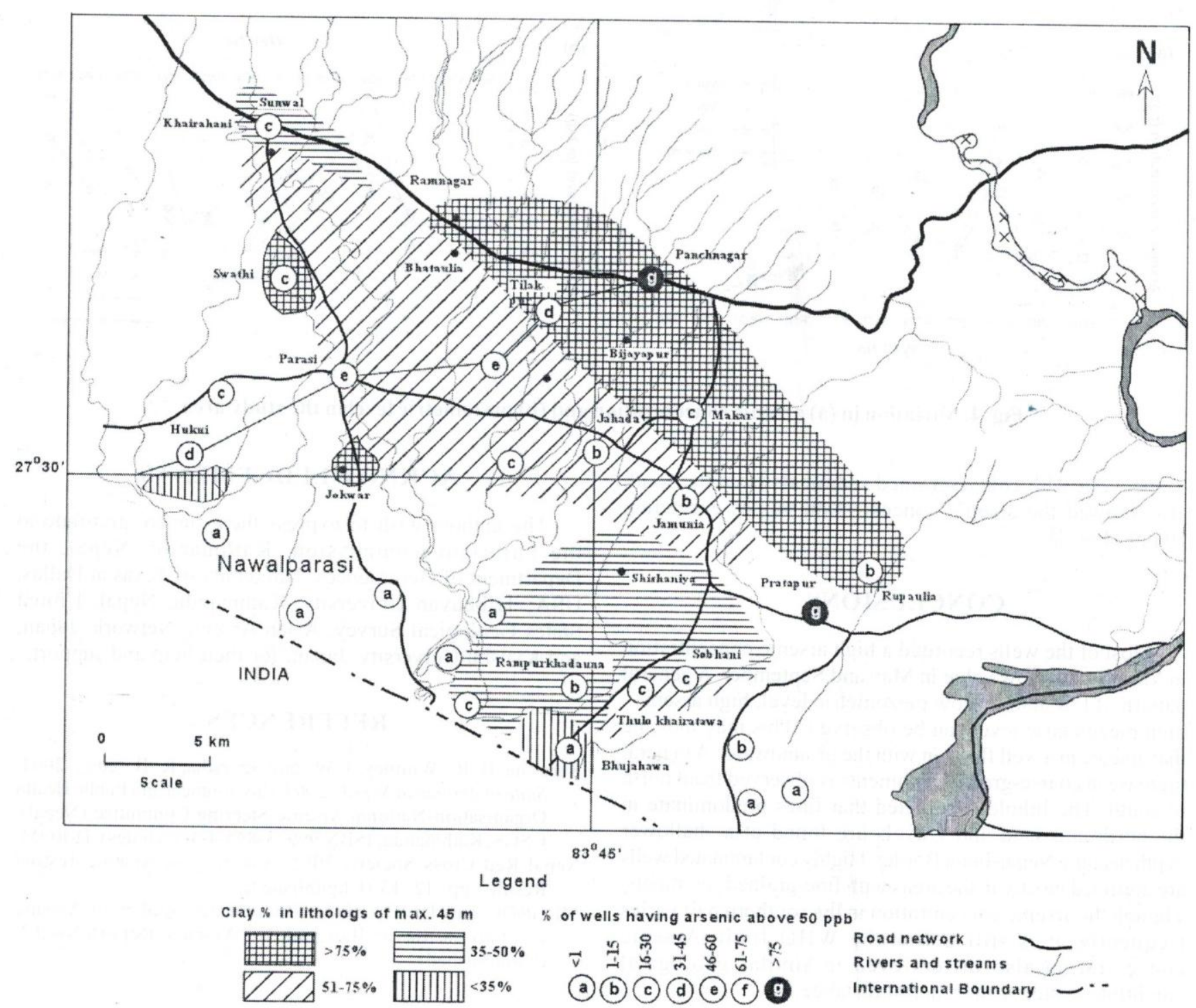

Fig. 3: Arsenic concentration and sediment distribution in the study area

subsequently decreased again to $215 \mathrm{ppb}$ in September. Similarly, in a well at Panchnagar (well number 8759), the initial Red Cross data showed the arsenic concentration of $95 \mathrm{ppb}$. The same well when tested in March showed the value of $357 \mathrm{ppb}$, which decreased to $160 \mathrm{ppb}$ in May, but increased to $175 \mathrm{ppb}$ in July only to decrease to $115 \mathrm{ppb}$ in September. With the above concentration and the variation, it is difficult to figure out any pattern of fluctuation, but it shows that there are large fluctuations in arsenic concentration even within the same season. This implies that wells should not be categorised as safe or unsafe on the basis of one-time data alone.

Another complicating factor is the variation in concentration even within a short distance. The NRCS data show that $80 \%$ of the wells at Panchnagar recorded a concentration higher than $50 \mathrm{ppb}$, but $15 \%$ of the wells showed a concentration below $10 \mathrm{ppb}$. The lithology of well numbers 8754 and 8761 is very similar and they lie in the same VDC, but their arsenic concentration values recorded by the NRCS are 0 and 228, respectively.

Fig. 2 shows the lithology and corresponding arsenic concentration in each well. In spite of some isolated wells containing more than $75 \%$ of clay even in the central part, a general decrease in the proportion of fines is observed from north to south. In the south, some wells contain less than $35 \%$ of clay. More than $75 \%$ of wells with predominating fines from the north and central parts recorded a high (more than $50 \mathrm{ppb}$ ) arsenic concentration. Similarly, less than $1 \%$ 


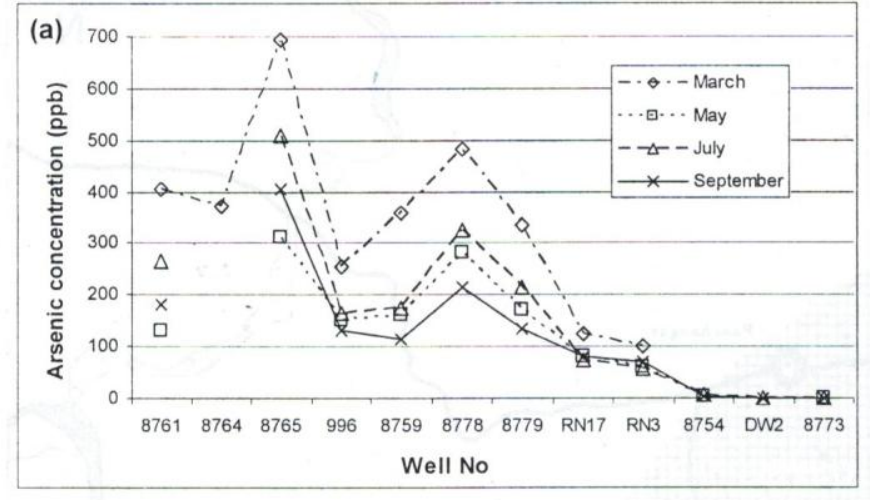

Fig. 4: Variation in (a) arsenic concentration and (b) piezometric level in the study area

of the wells with coarse-grained sediments from the south also showed the arsenic concentration values exceeding 50 ppb (Fig. 3).

\section{CONCLUSIONS}

Most of the wells recorded a high arsenic concentration in March, and a low value in May and September. A general pattern of low arsenic-low piezometric level, high arsenichigh piezometric level can be observed. This may indicate that arsenic in a well flows in with the groundwater. A general increase in coarse-grained sediments is observed from north to south. The lithologs depicted that fines predominate in the north and sand and gravels are found at a shallower depth near the Nepal-India Border. Highly contaminated wells are confined mostly in the areas with fine-grained sediments. Though the arsenic concentration in the southern part varies frequently, it is still below the WHO limit. Arsenic concentration also differs even in similar geological conditions within a short aerial distance.

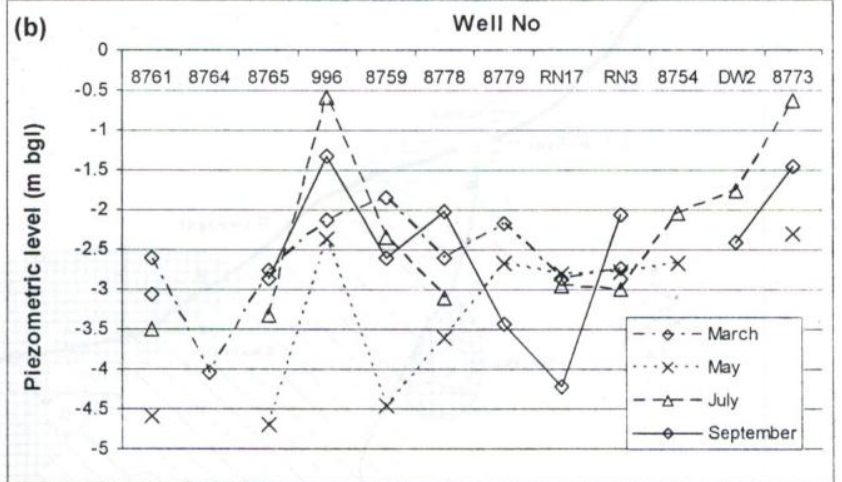

The authors wish to express their sincere gratitude to the Fulbright Commission, Kathmandu, Nepal; the Department of Geosciences, University of Texas at Dallas, USA; Tribhuvan University, Kathmandu, Nepal; United States Geological Survey; Asian Arsenic Network, Japan; and Kyushu University, Japan, for their help and support.

\section{REFERENCES}

Shrestha, B. R., Whitney, J. W., and Shrestha, K. B. (eds.), 2004 , State of Arsenic in Nepal - 2003. Environment and Public Health Organisation-National Arsenic Steering Committee (Nepal), USGS, Kathmandu, ISBN 99933-895-4-4, includes CD-ROM. Nepal Red Cross Society, 2001, Summary of Arsenic Testing Results, pp. 12-13 (Unpublished).

MLGRDC and DFID, 1998, Groundwater Studies of Arsenic Contamination in Bangladesh, Arsenic Report No 17, (Unpublished) 